$\underset{n}{\mathbf{m} n} \mid \begin{aligned} & \text { south } \\ & \text { asia }\end{aligned}$

samaj multidisciplinary

','

South Asia Multidisciplinary Academic Journal

$12 \mid 2015$

On Names in South Asia: Iteration, (Im)propriety and Dissimulation

\title{
Introduction. On Names in South Asia: Iteration, (Im)propriety and Dissimulation
}

Veena Das and Jacob Copeman

\section{(2) OpenEdition}

Journals

Electronic version

URL: http://journals.openedition.org/samaj/4063

DOI: $10.4000 /$ samaj.4063

ISSN: $1960-6060$

Publisher

Association pour la recherche sur l'Asie du Sud (ARAS)

Electronic reference

Veena Das and Jacob Copeman, «Introduction. On Names in South Asia: Iteration, (Im)propriety and Dissimulation », South Asia Multidisciplinary Academic Journal [Online], 12 | 2015, Online since 27

October 2015, connection on 19 April 2019. URL : http://journals.openedition.org/samaj/4063 ; DOI : $10.4000 /$ samaj.4063 


\title{
Introduction. On Names in South Asia: Iteration, (Im)propriety and Dissimulation
}

\author{
Veena Das and Jacob Copeman
}

1 Do names require a context in order to determine who a name refers to or are names the example par excellence for words that do not require a non-linguistic context to be specified? Since Russell's (1911) classical paper on this theme, proper names have been treated as a test case for theories of reference in philosophical debates. Whereas those in favour of

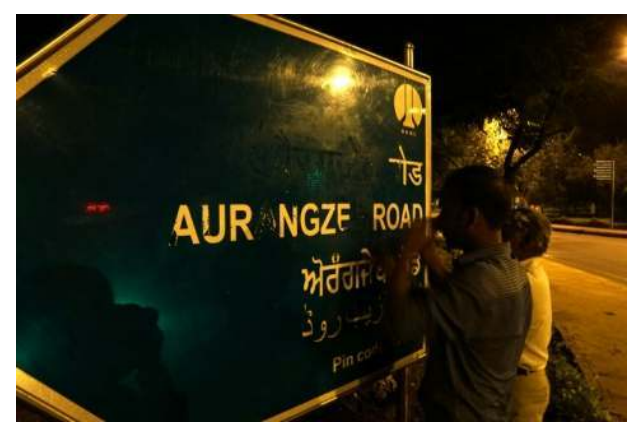
contextualism insist that names are a species of indexicals, the proponents of anti-contextualism squarely place the discussion of proper names within a definite description paradigm, applying Russell's original argument (with some important modifications) that names are essentially forms of concealed descriptions whose main function is to identify the bearer of that name. Of course, there is always the possibility that the description leads us to conclude that the bearer of the name does not exist, a point that has profound implications for the ghostly existence a name can take at the death of its bearer. Since a proper name is not explicitly a description, though, it becomes clear that we are asked to look below the surface to see what kind of background descriptions must be present for proper names to function. Whether we think of names as directly-referring rigid designators (Kripke 1980), indexicals (Recanati 1997) or definite descriptions (Frege 1953, Russell 1911, Searle 1958), all these theories of naming privilege the one who is taking the name-e.g. if a number of people say that Nikhil was the character in a Tagore story they are assuming background descriptions that include some such facts as: Tagore lived in Bengal, he was a writer, and he wrote a novel called Ghore Baire in which Nikhil was the zamindar. Not everyone who has some background information about Tagore or Nikhil will have all the relevant 
information, but there will be considerable overlap between those who use the names Tagore and Nikhil, say, in a conversation on literature-enough agreement for one to conclude that the names refer to an author and a character. The discussion can get more complicated if we ask if the bearer will remain the same in all possible worlds as the idea of names as rigid designators suggests (Kripke 1980), but the focus remains on identification of the bearer.

2 Discussions that take reference to be the primary issue in naming elide certain important questions. The papers in this special issue draw from both ethnographies of names and naming practices in South Asia and theories of names embedded in literary texts, rules of grammar, or in aesthetics to open up other aspects of names. For instance, do names carry existential meanings for those who give or receive them? In what way do social conventions of naming or prohibitions and taboos on names make name-words into containers of emotion? While names function as social designators of say, religion, caste, gender, race, do they also embody the experience of being this kind of person in this kind of social milieu? Instead of drawing sharp boundaries between theory and ethnography, or between discussions in Western philosophy and Indian texts, the papers demonstrate how concepts emerge in the intersection of these formations and provide us a way of thinking of names that provides a lens with which to understand important processes of self-making and everyday violence in South Asia. At the same time, the papers raise questions that contribute to ongoing debates about names and broader processes of signification.

3 One important way we could think of the challenge to the centrality of reference in naming comes from the insightful observations of Peirce. The essential point, if we ignore Peirce's obsession with generating typologies of signs and naming each type and subtype, is contained in the following observations on proper names:

A proper name, when one meets it for the first time, is existentially connected with some precept or other equivalent individual knowledge of the individual it names. It is then, and then only, a genuine Index. The next time one meets with it, one regards it as an Icon of that Index. The habitual acquaintance with it having been acquired, it becomes a Symbol whose Intepretant represents it as an Icon of an Index of the individual named (Peirce 1903: 329, as cited in Weber 2008: 354).

There are two important observations to be noted here. First, in the case of the descriptive theory of names, the crucial moment is when the speaker of a name is askedwho is Nikhil? Or who is Alexander?-and, she responds with a description. For Peirce, however, this moment is but one moment-names, he said, course through life and at some junctures they act as indexes while at others as icons of the index. Said otherwise, one learns to apply a name to a person as a matter of habit-names are objects of acquaintance; they are not propositional knowledge. Thus, as one becomes habituated to speak a particular name for a particular person, there is a shift in the quality of the experience of naming. The temporal unfolding of different contexts through which one's life moves will also bring to the fore many new ways of experiencing one's own life. Think of Romeo-'My name, dear saint, is hateful to myself, Because it is an enemy to thee.' This aspect of Romeo's own name-that it would become an obstacle to his own self-would not have been offered in any background description given to provide reference.

$4 \quad$ Kripke had already noted in his theory of names as rigid designators that because there is no single correct description of a person, none of the descriptions a person associates with a name might uniquely pick up the object or person whose name it is. Peirce, however, was arguing something different-namely, that the semantic and pragmatic 
aspects of names could not be separated. Finally, we draw attention to the darker aspects of the name brought out in the poignant writing of Derrida (1995) on what he called the (im)propriety of the proper name: 'What is a proper name-anyway? A name is never proper...' Resonating with Derrida's overall take on our being in language as what makes us vulnerable because of its iterability, in the specific case of names too, he is able to draw out what is difficult to name in the name, what is the surplus, what dark potentials lie in our using the name as a vocative-to call another or to be called by another. These matters touch on registers of the name which bring it into the vicinity of ancient magic, the vulnerability of the self, and the fragility of things on the one hand and aspirational politics, defiant self-making, as well as the conjoined joys and burdens of belonging to the social, on the other. We shall see in subsequent sections how the papers in this volume speak to all of these registers of names-as definitive descriptions, as temporal entities, as affect-saturated words with a physiognomy, and as participating in and dangerously becoming imbued with what becomes the occult in our social and economic life. It is important to underscore here that the authors of these papers are not taking concepts from the discussion of names in say, Wittgenstein, Kripke, Peirce, or Derrida, and then applying them to their ethnographies. Rather, they are joining this conversation through both ethnography and the texts that they evoke, placing reflections on names wherever they appear in the weave of life as providing the scaffolding for anthropology's theory. ${ }^{1}$ Let us turn then, first, to the signature theme of anthropology-viz. what relation does the singularity of the individual bear to the sociality in which relations are always, already embedded?

\section{Sociality and singularity}

5 In a decisive intervention on names, Lévi-Strauss argued that names are instances of social classifications that move between a horizon of individuation, on the one hand, and more general categories of the social, on the other-i.e. between proper names and common names. In totemic societies, for instance, names of individuals are all taken from some part of the larger totemic complex. Given Lévi-Strauss's concept of the social as essentially a form of social classification, and the idea of explanation as disclosing an arrangement (see Benoist 2008, Das et al. 2014), it is not surprising that he saw individual names as pointing to a unity (of the totemic complex) divined and claimed in advance (Lévi-Strauss 1966: 174-75). At the same time he also realised that an individual name might mark an event at the time of the individual's birth or it might mark a specific characteristic of the individual-such as a deformity or a position in relation to a sibling. Thus names, for Lévi-Strauss, cluster around two poles-one in which their relation to the collective is proclaimed and another in which names reflect individual creativity. In between these two poles Lévi-Strauss noted several indeterminate cases that accounted for varying practices with regard to names given to humans, animals, things in nature, or to social artefacts.

6 Although Lévi-Strauss's formulations on naming continue to provide an important framework for thinking of names as a lens with which to view the relation between the individual and the collective, his evaluation of totemism as a more robust way of conceptualizing the social as compared to sacrifice (which he tended to associate with individual desire) led him to neglect what might have been a very interesting provocation for his theories-viz., the evidence from South Asia on names given, for instance, to 
sacrificial priests, or to deities in devotional practices (see Das 1983; Malamoud 1998). Indeed, we (the editors) reiterate that there is a rich field open for exploration in which material on naming practices in South Asia could be made to directly join the conversation in social theory and philosophy. On the one hand we can draw on this conversation in a way that (we hope) allows us to see classic themes in the study of South Asia anew. On the other, the spirit of this special issue is dialogic-it offers something back to what it draws from: theoretical formulations on names in philosophy and social theory

\section{Names as definitive descriptions}

7 Commenting on the tightness of connections between names and the social identity they signalled, the narrator in one of Amitav Ghosh's novels, Sea of Poppies, reflects: 'The provenance and origins of strangers often provoked Neel's curiosity: in Bengal it was so easy to know who was who; more often than not, just to hear someone's name would reveal their religion, their caste, their village. Foreigners were, by comparison, so opaque: it was impossible not to speculate about them' (Ghosh 2008: 101).

8 At one level, then, it seems that it is in the nature of names that they are tightly connected to the bearer (although the background descriptions are less about the personal attributes and more about the social position-the divined unity of the whole as Lévi-Strauss contended). Yet scholars of South Asia have made this issue more complex by their attention to historical processes through which names came to be fixed. In his work on marriage and rank in Bengal, Inden (1976) points out two interrelated conceptions-one is of gotra names for members of the Brahmin (and other higher) castes which were the original names of the Brahmin priest-preceptor, primarily used for ritual purposes and for determining caste exogamy. These words, like other words in the Vedas, says Inden, were considered to be subtle and powerful substances necessary for the correct performance of Vedic worship. In an uncanny way, one can see the power of the gotra name resurfacing now in the spate of executions of couples ordered by khap Panchayats in Haryana because they married each other despite sharing the same gotra name (Kapila forthcoming). Though such kin related killings are often assimilated within the category of 'honour killing,' in these cases what was at stake for the Panchayats was the suggestion of incest-thus sameness of name came to signal sameness of substance in the context of ritual and kinship.

The second, interesting point contained in Inden's description, though, takes us not to the non-arbitrary relation between name and social group but the contingency surrounding a name which can alter the trajectory of the person's fate (1976: 55-56). One of the incidents recounted in a medieval text (1032 AD) occurs at a point when genealogies are being fixed in the king's court. For Inden, the main point of the story is to show how Shudra kings in this period used their power to settle the disorder and incoherence that had developed by fixing the ranks among and within castes, and prescribing rules of marriage that preserved the boundaries of these groups. The story goes as follows: the Shudra King Adisura invited five learned Brahmins from outside his kingdom to compensate for the lack of learned Brahmins of good conduct within the kingdom. Each Brahmin arrived with a devoted Shudra and the king was trying to determine which name belonged to which person. In the process, the name of the last Shudra in the team was given as Dasratha Guha. On hearing this name, people burst out 
laughing. Inden explains in a footnote that the word guha is similar to guhya meaning anus-which is what caused the mirth. To cut the story short, having been consequently demoted in rank this person decided to leave the kingdom and settle elsewhere. The moral of the story, if one can render it as such, is that the official story of the matching of name and good conduct holds in the first four names of the series but in the fifth case, the pattern is broken as laughter bursts out, and thus for the moment loosens the tight order that the king is trying to construct.

An important insight on names we get from this text is that the power to name and to fix identity is something the king or the state tries to do-one might say that the right to name might even define power. Consider the various laws pertaining to the right to name your child in European countries. In Germany, for instance, one must be able to tell the gender of the person from the first name. Further you cannot use a last name, or the name of a product or object as a first name. All names given to babies must be approved by the office of vital statistics, the Standesamt, in the area in which the child was born.

11 The 'becoming legal' (Deseriis 2015: 23) of the proper name is of course central to the story of the modern state in South Asia. The institutionalisation and fixing of the surname by colonial governments (Scott et al. 2002) saw the name enter 'a whole network of apparatuses (demographic records, criminal records, tax records, voting records, immunisation and health records) through which the state can both identify an individual and deploy a series of calculations and operations whose domain and target is the population' (Deseriis 2015: 23). Specifically in India, the colonial complaint was that personal names were too recurrent ${ }^{2}$ (and contributed to the native propensity for impersonation), while place names, too, required standardisation (Singha 2000:6). Moreover, bureaucrats lamented, 'signatures in the indigenous scripts, Persian or Devnagri, [were too] difficult to decipher for verification' (Singha 2000: 60).

Corresponding to the state's interest in enumerating and identifying each individual or group entity and in developing the necessary bureaucratic apparatus to enable this, subjects too try to use the apparatus for their own strategic interests. Thus, for instance, the attempts to standardise and record caste names in the census in the colonial period (see, for example, Nesfield 1885) led to a tremendous volatility as different castes jostled to take on names that were reflective of a higher caste status (Srinivas 1957, Jayswal 2001). Competition for the state resources earmarked for the scheduled castes, scheduled tribes and other backward castes, has now led to agitations for changing caste names in the other direction. The point is that in both cases the groups and individuals do not simply submit to official initiatives in a passive manner but use these new opportunities to strive for new identities in the eyes of the state.

13 We do not mean to underplay the repressive practices of the state or of religious authorities. For instance, the Portuguese inquisition established in Goa in the $16^{\text {th }}$ century strictly prohibited many Hindu practices including the taking of Hindu names (Robinson 2000, Henn 2014). Similarly, identifying individuals considered prone to crime and expelling them from British territory was an important part of policing in colonial India (Singha 1998). Yet fears of forgery, misidentification, and corruption haunted these governmental efforts. Thus the name might be seen as signalling both the possibility of surveillance by the state and strict regulation of who can take which names as well as opening up a space for aspirations to be recognised by the state and the manipulation of names to trick the state through duplication of documents, forgery and endless possibilities of petty corruption. 

Delhi is that of their profusion (the child having many names) and situational contingency (different names come into play in different situations). Having left their natal places, street children in Delhi take on a number of different names in order to elude an official identity assigned by origins. The names they bear are improper names in Deseriis's (2015:3) sense in being 'explicitly constructed to obfuscate both the identity and number of [their] referents.' In consequence they disrupt their own ability to act as a technology of government and categorisation; and indeed, for these children, their value lies precisely in this fact. However, where in the cases discussed by Deseriis many people use a single name to create a 'shielding effect, ${ }^{3}$ in those analysed by Steinberg a single child may use many different names in order to continue to elude their families and authorities; which is to say that, here, the shielding effect of the name comes from having many of them.

Why do these children run away? For north India, at least, children in rural villages tend to decide to leave home due to distressing domestic circumstances rather than acute poverty, a finding that is in line with Conticini and Hulme's (2007: 207) observation from Bangladesh that 'the breakdown of social relationships within the household, and not economic poverty, is the main cause of child migration to the street.' Having left, children tend to not want to go back, and are intensely aware that this is exactly what state authorities and charitable NGOs have in mind for them if apprehended. Emphasising the situational onomastics engaged in by these children in order to evade being tracked and documented, Steinberg also shows how the names they bear cross community boundaries (e.g. Akhil-Azeez) and allude to their bodily form (Petu references a scar on the child's stomach [pet]; Kalu the darkness [kalima] of the child's skin). In situations of fluid and contingent biography, argues Steinberg, the body emerges as 'the sole available durable slate on which to fashion and display self.'

The papers by Vaibhav Saria and Deepak Mehta in this volume explicitly discuss how the law might act to restrict the names one can take in order to achieve semiotic stability, as well as ways in which this power to create a stable identity of the jural person through a control over names might slip from the hands of the law. Saria's paper on the namechanging practices of the hijras in Orissa shows how the changes from male names to female names and then from one female name to another are embedded in events that might mark both the birth into a new identity and a new set of relations, as well as the death of relations that have become brittle through the instability of desires. Saria interprets the play with names as expressive of a make-believe reality in which the wish is that taking a new name might enable one to erase the past signalled by the earlier name and to begin life anew. This subjunctive mode of living, however, meets its limits precisely in the law when a hijra gets caught in crimes that could be petty (e.g. begging in trains) or grievous (such as murder). While in the case of petty crimes it becomes possible for hijras to negotiate with lower level officials through bribery or through links of locality, in the case of crimes of greater enormity, the play with names comes to an end as the courts invariably settle for the hijra's male name as indicative of the true and authentic name-treating all other names (including their female ones) as criminal aliases. Saria's interpretation of this complex terrain provides a fascinating glimpse of the judicial unconscious with regard to masculinity and sexuality and the hinges in judicial reasoning. The courts are able to short-circuit the need to provide connections between evidence and conclusion by the device of the male name that then becomes a condensed 
metaphor for the male disposition toward violence. Interestingly, Saria shows that in cases in which hijras are presented as victims of violence (rather than perpetrators) the courts continue to use their female names.

The question thus becomes: true and authentic name for whom? We see a similar maladroit insistence on the first-given name as the true name in Facebook's decision to deactivate the accounts of drag queens:

A Facebook spokesman said the company requires people to use their real name to promote accountability, but drag queen Sister Roma says that is her real name. 'If you ask anybody who I am in and out of drag, my name is Roma. So currently my profile says Michael Williams next to this gorgeous picture of me, and it doesn't make sense,' she said. 'People don't look for Michael Williams, and it's not who I am.' San Francisco Supervisor David Campos [...] said fake names can protect people who are transgender, bullied, or escaping domestic abuse. ${ }^{4}$

Contestation concerning the power to name a name as true or proper has deep roots in the subcontinent, with personal names frequently thrown up as special status indicators of fallen authenticity. Rupa Viswanath (2013:133), for instance, cites the poem 'Ramaswamy becomes Ramsay' which was published in a south Indian nationalist newspaper in 1923 that ridicules the pariah Christian convert: 'He therefore [...] donned a collar and tie, / Then added a waistcoat and a watch with trousers by and by... / Then came a pair of socks inside his shoes... / The chrysalis burst, the butterfly / Ignored his parcherry set / And now, 'one Mr. Ramsay' dwells/ A swell-in Padripet.' The tone of V.S. Naipaul's famous essay 'Jamshed into Jimmy' (2002) is not dissimilar to the poem's and finds its present-day analogue in the proliferation of literature on South Asian call centres and 'locational masking', which eschews the possibility of, for instance, an analytic of performance in construing the 'western' names taken on by employees as condensed metaphors of the counterfeit modernity of 'new India.' What we might point towards here is that such accusations of compromised authenticity in fact possess the characteristics of insults, where we understand the insult to be 'an act of violence [...] [that] denies its very name to its victim by imposing another one [here the so-called true or authentic name] upon him/her. This process is enjoyable yet it can break an individual, even destroy him' (Bouchet cited in Blom \& Jaoul 2008).

The becoming legal of the proper name that we have been discussing is not, of course, restricted to personal names. No absolute distinction between personal and place names exists so far as persons and places may be named after one another. Scott (1998: 66-67) notes that geographical location formed a key plank of the local logics that were present in the establishment of surnames (e.g. in England, the surnames Hill and Edgewood). For Sikhs wishing to adhere to the orthodox proscription on the use of caste surnames, but who nevertheless seek stronger differentiation than that provided by the titles Singh and Kaur, ${ }^{5}$ use of place names as surnames can provide a handy workaround (an example is that of the current Chief Minister of Punjab, Parkash Singh Badal-Badal being the name of his native village). In other parts of India as well (e.g. western India), use of place names as surnames is utterly conventional.

Recent scholarship on the region has focused on state-sanctioned or initiated renaming of places and structures. For instance, it has been argued that the state performs its sovereignty through official acts of (re)naming of structures and places that come to authorise and legitimate particular political identities (Hansen 2001). Somewhat like the way in which the Indian state offers recognition to communities of their wounding at the hands of specific cultural productions (books, films) through acts of censorship as 
sovereign gifts (Cohen 2010), we may suggest that state authorisation of name changes according to the wishes of communities who can be thought of as wronged or deprived sometimes takes the form of a kind of sovereign gift of the name (e.g. the well-known case of the 1970s Dalit namantar movement, ultimately successful, to rename Marathwada University in Aurangabad after Ambedkar). ${ }^{6}$

Geographer Maoz Azaryahu (2011) uses the terms 'toponymic cleansing' and 'symbolic retribution' to describe the often systematic renaming of streets and places that can take place after regime changes. Azaryahu refers, for instance, to the changing of street names connected with South Africa's apartheid past shortly after the African National Congress came to power. The cover image of this special issue depicts the physical renaming of Delhi's Aurangzeb Road, which one night in August 2015 became A.P.J Abdul Kalam Road. However, the year before the official renaming, the Delhi Sikh Gurdwara Management Committee (DSGMC) had petitioned Prime Minister Modi to rename the road after the ninth Sikh guru, Guru Tegh Bahadur-a historical figure who, in 1664, was executed on the orders of Emperor Aurangzeb. ${ }^{7}$ If this was an attempt to enact symbolic retribution, there is also an echo of the type of forgetting that Connerton (2008: 60) has called 'repressive erasure':

the condemnation of memory (damnatio memoriae) [...] was inscribed in Roman criminal and constitutional law as a punishment applied to rulers and other powerful persons who at their death or after a revolution were declared to be 'enemies of the state': images of them were destroyed, statues of them were razed to the ground, and their names were removed from inscriptions, with the explicit purpose of casting all memory of them into oblivion.

We might add, though, that whatever the intention of state and other actors in seeking new names for things, complete erasure of the replaced name is never a foregone conclusion. Instead of expunging the name, what may occur is its spectral doubling. The state's power to (re)name can thus come to stand in ironic relation to its concern to fix the reference.

21 A different, more nuanced and complex perspective on toponymy is provided by Deepak Mehta in his paper in this volume on the long legal dispute (1889-2010) over the right of Muslims and Hindus to offer worship in the Babri mosque and a virtual Rama temple in Ayodhya. The controversy this dispute generated centred around the question of whether Ayodhya was the birthplace of Rama and whether a temple was demolished by the Muslim invader king, Babar, in the $16^{\text {th }}$ century to build a mosque on that site. The legal controversy raised a host of important issues and Mehta has been diligently ploughing through the more than 1000 pages of the legal archive to build a careful and detailed history of the dispute (see Mehta 2015). His paper here examines specifically the mirroring and the eclipsing of the names of Rama and the name of the Babri mosque. ${ }^{8}$ Through tracking changes in epithets attached to the name of Rama in the various versions of Ayodhya Mahātmya (the Glories of Ayodhya) that are written in the genre of Sthala Puranas and the mahātmya literature, ${ }^{9}$ as well as the legal petitions, judgements, and stay orders that are available in the judicial record, Mehta gives us three important insights. First, he shows how the epithets attached to the name Rama change over time so that as the deity acquires jural personality it is transformed from a kingly deity to a legal minor (as the name Ram Lalla, little Rama, implies). Second, the specific proper name given to the mosque (Babri) slowly disappears and is replaced by the legal term, 'the disputed structure', as if continuing to refer to it by a proper name would give it a substantial presence. The demolition of the Babri mosque by a crowd composed of Hindu 
kar sevaks on December 6, 1992, makes the place itself a spectral entity, and the disappearance of its name in the judicial record mirrors this spectral quality of the mosque as it moves from being a physical structure to a kind of wound in the landscape. Mehta argues that in a related move, the attempt to give a jural personality to the deity by which its name is made to stand for its rights-as if the deity were a person-becomes the reverse image, so to say, of the disappearance of the proper name of Babri from the (now) demolished mosque. Finally, he also shows how the mutual conjoining of the name of Ayodhya and the name of Rama in the mahātmya literature becomes a formative influence in the deliberations of the court, which also ultimately leads to the disappearance of the name of Babri since no such intimacy can be evoked between the name Babar and the name Ayodhya. The papers by Saria and Mehta show the complex terrain of legal reasoning in which names come to play a significant role, but one that could be obscured because it is never explicitly taken into account.

\section{Name changing as border crossing}

On February 26, 2012, the Times of India, a prominent daily, carried a headline, 'Now, Women Can Retain their Maiden Name.' The news item pertained to an amendment of a crucial rule under the Family Court Law by the Bombay High Court, by which (contrary to an earlier rule) a wife who had not changed her name after marriage by publishing it in the official gazette would be allowed to continue to use her maiden name. The court ruled that a woman could not be forced by a court to write her name in the form of her first name followed by her husband's first name and his surname while making a marriagerelated petition. The amendment came about because of a struggle launched by the prominent feminist lawyer, Flavia Agnes, and the NGO Majlis, which works for women's rights. It reflects on the understanding of names and judicial conventions on names as a significant feature of the struggle for women's rights in India. ${ }^{10}$

As we saw in the last section, the law has an interest in the regulation of names and thus views changes in names with some suspicion. Yet as Mehta and Saria both show, appearances and disappearances of certain names over others (e.g. male names replace female names in the case of the hijras, and the name Babri disappears to give place to an unnamed 'disputed structure' in the case of the Ramjanmabhumi-Babri masjid dispute) are steeped in ideologies of gender and sectarian politics. How would looking at conscious strategies of name changing illuminate a different dimension of names-viz. the aspiration toward an idea of the self as otherwise than one is on the one side, and strategic manipulation of one's public image, on the other? It is not only individuals who might experiment in this manner with changing names (Khosravi 2012), but also corporate entities from royal households to multinational corporations. Thus, for instance, during World War I, the British royal family changed its name from the House of Saxe-Coburg-Gotha to the house of Windsor to take away the foreign tinge in the name.

Coming to personal names, Copeman's paper provides a discussion of strategies to change names on the part of several secularist and rationalist organisations in Punjab and elsewhere in India. He identifies two main strategies employed for the production of 'secular names': purification of the caste and religious connotations of names on the one hand, and multiplication of those connotations in the giving of boundary-crossing names on the other. Thus, for instance, using a generic term such as 'Kumar' as a surname removes caste identifiers, while conjoining a Hindu name with a Muslim one (Ram Rahim, 
Ashis Azam) creates a boundary crossing between Hindu and Muslim identities. Common to all such strategies is a rationale that seeks to break the association between the name and a pigeonholed identity. One could also look at sibling names in the case of HinduMuslim marriages in which one child might be given a Hindu name and the second a Muslim one, or consider approaches such as that employed by film actor Shahrukh Khan and his wife Gauri: 'I gave my son and daughter names that could pass for generic (panIndian and pan-religious) ones: Aryan and Suhana. The Khan has been bequeathed by me so they can't really escape it. I pronounce it from my epiglottis when asked by Muslims and throw the Aryan as evidence of their race when non-Muslims enquire. ${ }^{11}$

While Copeman argues that the different strategies employed demonstrate the extent to which naming has become subject to experimentation amongst rationalists and secular activists, he is careful to point out that these strategies make sense only in the background of experiences of the close relation between name and social identity. We draw attention to the fact that even in cases such as that of the Arya Samaj, ${ }^{12}$ which banned the use of caste names, the strong association between naming and religious identity was important in their strategies of conversion-for instance, in their work among communities that were not clearly identified as either Hindu or Muslim, such as the Bishnoi community in parts of Rajasthan and Uttar Pradesh. Bishnois considered themselves Hindu but practised many Islamic customs such as burying the dead instead of cremating them. Arya Samaj activists worked with the community not only to change such customs, but also to change names from Muslim to Hindu ones (Sikand \& Katju 1994). In the opposite case, Chatterji (2012) reports on the traditional Muslim communities of scroll painters (Chitrakar) who earned their livelihood (and now their fame) by depicting Hindu mythological stories in their scroll paintings and in the accompanying narratives that they recited for their patrons. However, as aspirations for more purified Islamic identities began to take hold of their imagination of self, the pressure to shed their Hindu names began to mount. ${ }^{13}$ The point is that the strong association between name and caste or religion is itself a result of different processes by which boundaries of groups were solidified both by their interactions with the state and with various kinds of reform movements, caste associations, and other mechanisms for removing any ambiguity with regard to the straightforward identification of name with the social group.

The semiotic stability or instability of sacred names in a multi-religious milieu is the problematic of Henn's essay on the genre of Puranas in which Christian stories were written in Goa. The essay asks, can the name of God be translatable? Are these translations evidence of attempts to build bridges across different religious groups or do they impose a stronger and more dominant language over the languages of groups that are falling into subordinate positions?

Is the name of God translatable? This is a question that has not only divided theologians but also influenced how we look at the academic study of religion. As Henn points out, at the heart of the idea of world religions is the notion that different religions are comparable because they have a conceptual and experiential place for the idea of 'god' that appears under different names. This notion may be challenged both by those who consider there to be a mystical link between name and deity (e.g. the phonetics of the name being tied to the kind of entity it is) and even more radically by the idea that a name might not function as a noun but as an adjectival quality, as argued by Das (2009) for Vedic gods. Offering a provocation on the notion of God from anthropology, Lambek 
(2009) argues that in translating the Nuer term kwoth by the term God for the most part in speech, Evans-Pritchard gets pulled in two different directions. Attentive to Nuer forms of speech, he sometimes treats kwoth as a product of discourse by systematically noting the situational quality of invocation and thus the range of meanings contained in the usage, but at other times use of the term God directs the reader to think of kwoth as a real and unitary being. For Henn too, as we shall see, the choice of a specific Konkani/Marathi term among the various ones available to translate the idea of the Christian God is never simply a question of technical problems of translation but indexes a particular play of power in competing claims over who holds the greater truth-Christians or Hindus?

Henn's analysis of the Christian Purana literature in Portuguese controlled areas on the Western coast is subtle and nuanced, and above all, he is mindful of the context within which such literature was produced. Thus, he shows that at the same time missionaries such as Stephens were employing stylistic devices drawn from Vaishnavite devotional literature, there was a ruthless campaign of destroying Hindu temples, breaking the idols in the temples and burning the very books from which the devotional styles were taken to render the Christian stories of Christ or the Virgin Mary intelligible to the new converts. Henn gives a fascinating account of the names through which the term God is translated and that served to simultaneously designate and circumscribe its semantic range. Thus, names such as Deva Bāpa (Father God), Vaikunțharāyā (Lord of Heaven) and Parameśvara (Supreme God) make the Christian God intelligible in local languages but also displace the Hindu gods-thus Vaikuntha (heaven) is mentioned but the name of Vishnu, who in Hindu cosmology is the ruler of heaven, is studiously avoided, suggesting that it is the Christian personages who are the creators and rulers of the world. Henn concludes on the sober note that the assumptions behind claims of greater tolerance and religious pluralism need to be treated with some caution, for underlying these ideas is the notion of religion as a universal. Yet attention to the issue of how exactly the vocabularies of Christianity, and especially the name of God, were translated into a Hindu world ${ }^{14}$ shows not simply an urge to make Christianity intelligible but also actions of iconoclastic destruction and semiotic appropriation/misinterpretation of the religions that Christianity was encountering.

\section{Publicity, vulnerability and the excess in the name}

When we move from religion to economics, we might expect to find that names of products fall into a more rational scheme of things. We learn that not only do products have a price but that there is monetary value attached to brands. Journals in marketing research, cognitive psychology, and economics carry influential papers on brand equity, brand alliances, and the legal apparatus for protecting brand names. From the perspective of a theory of signalling, brand names concern the need to provide information to consumers about the unobservable qualities of the product that is being sold; to use the phenomenological idea of 'appresentation,' the brand name is appresentational in giving an account to consumers of 'what lies spatially and temporally beyond their reach' (Schutz \& Luckman 1989: 2, 131-32). ${ }^{15}$ On the other hand, Tülin and Swait (1998) cite the marketing adage: 'So the battle over brands will go on. Do not be fooled into thinking that it is really about baked beans, soap powder, or notebook computers. It is all about information. And it will continue for as long as buyers need and want that information. Don't get left on the shelf.' From the perspective of information 
theory, the market works on partial information-so just as standardisation of labels works to allow consumers to compare similar products (Teisl \& Roe 1998) in terms of components (but not price), so brand names can be seen as differentiating devices that communicate a guarantee about a product's quality as an aid for consumers to make rapid decisions. However, as it turns out, things are not so simple.

First, consider how names can also trick one into making decisions that are not based on rational calculation and second, how the surplus in the name-its hidden potential, if you will-releases a series of events (or quasi-events) that were not anticipated.

31 Cooper, Gulen, and Rau (2005) studied the fund flow patterns in mutual funds conditional on name change and found that there was a significant correlation between names that were changed to resonate with names of more successful firms in the market and increased flow of investment funds. On the other hand, when names were changed in a negative direction and resonated with names of other less successful fund management companies, there was a corresponding decline in the flow of funds. Significantly the change in name did not correspond to any change in the portfolios of the said mutual funds. This relation between change of name and flow of funds held even for the firms whose holdings did not materially reflect the style implied by the new name-for instance, changing the name to include the term 'large' did not mean that the firm was changing its strategy toward larger holdings. In these cases, it would seem that names are not a signalling mechanism that provides quick information to consumers for decisionmaking but are rather a trigger for behaviour that responds to other mechanisms for decision-making.

The papers by Mazzarella, Heslop and Bharadwaj might be profitably read in tandem with the questions posed by the literature in economics and marketing research on whether names as they function in different kinds of markets (markets for brand names or for perishable goods) as well as in the public domain where claims over scientific reputations are monitored, bring out more than the function of signalling.

Mazzarella poses the question succinctly: what kind of name is a brand name and what relation does it bear to the proper name of a person or a definable physical entity such as a star or another insentient being? At the start one might say that in the case of humans, the name is embedded within a conversation-I might be addressed by another by my name and in turn I might proclaim my name to introduce myself to another. In contrast, insentient objects that are given names cannot make these names part of their own experience of being called (or interpellated). However, as Mazzarella shows, there can be a feeling of the 'I' as one slips in the course of a conversation to speak in the voice of a brand name. ${ }^{16}$ How do such notions as that of a voice help us understand what goes beyond the function of signalling in the name?

When we want to understand the meanings of words we do more than look them up in a dictionary, for an important aspect of learning how to use a word is learning how to project it into new situations. When it comes to brand names, Mazzarella shows that a brand name might be treated both as singular, since its function is to differentiate the product it represents from other products, and multiple, since as a brand name acquires publicity and garners trust around it, new products might be added to it. For example, how does Virgin extend from being a name for a recording label, to refer to a music store, to hotels, or to an airline? Is there a surplus in the name that gathers meaning through these extensions? Mazzarella gives us a fascinating glimpse into board room discussions 
as marketing and advertising executives seek to decide on a brand name that would assist in opening up a market for a new product and wrestle with the issue of how the new name would relate to the mother (i.e. original) brand. How would a name signal that it is a sub-brand and not become a substitute for the original brand by overcoming it completely? What was being marketed was a new combination of products, now available in one package, which were otherwise available as single products. In such cases, how would a marketing executive imagine becoming a consumer asking for that product by using the new name? Reviving the notion of participation in the manner in which early anthropologists (e.g. Lévy-Bruhl 1926) thought of totemic names as sharing a substance with the image of the totem, as well as the animal itself, Mazzarella provides one important route to think of names and the surplus they contain beyond reference.

The vulnerability of the name in the case of brand names which try to create markets for products within the scene of stranger sociality, as Mazzarella notes, comes from the mimetic ability to copy the name and use it for an inferior product, or to take a similar sounding name (a practice we saw documented in the case of financial management firms) and thus to steal a part of the name and the market share. In the case of the wholesale vegetable market in Dambulla, in the middle of Sri Lanka, studied by Heslop, it is signboards that are carefully designed to not only convey information but also to build trust in the product by references to family name, and to invite the consumer to a particular kind of participation with the product that would signal the legitimacy of new desires. Yet there is only so much you can do when the product in question is fresh vegetables-highly perishable and almost too quotidian-and the vegetable sellers are already of low status in the moral economy of caste. Yet, Heslop is able to open up a different dimension of names as he shows how the signboards of small businesses and the names they carry provide condensed histories of past relations within the family and kinship group. His discussion, for instance, of Saman Bakers, a family owned business run by a young man, Saman, is illuminating. At first glance, one might be led to think that the signboard with his name is surely indicative of the young man Saman's autonomy and capacity for independent decision making. Yet one learns that the son did not choose to name the bakery after himself; it was the father who gave the name of his son to the bakery, but he did not relinquish financial control over it. Thus moving in a reverse mode, the name of the son becomes, along with the bakery named after him, the property of the father. This is not only a textual inference on the part of Heslop but rather a result of close observation of the interactions between father and son, as well as the stories of familial conflict and frustration that Saman shares. There are other cases, of course, in which new familial relations are created or strengthened by the movements of names between persons and signs; there are also instances of consultations with monks or other religious personages to arrive at a name that will be auspicious and bring good fortune. The references to luck and the ability to arrive at the right name that will not be a mismatch between business aspirations and the hidden potential contained in the name for good or evil, point to a moral economy in which notions of luck, fortune and misfortune-perhaps an occulting of the obviousness of the relation between names and caste or kinship-is seen as an essential feature of survival in the fierce competition of the market and its presumed impersonality.

Bharadwaj's paper in this volume engages some of the discussion in Mazzarella's by asking: what does a name mean as a common noun and what adjectives might describe its qualities? Or to put it differently, what does it mean to have a 'good' name or a 'bad' 
name, the latter felicitously captured in the Hindi/Urdu usage of the term badnam? Although Bharadwaj's research is on stem cell therapy and the struggle over maintaining a good reputation, he does not start with the political economy of science, or with what one might call a market for truth. Instead, he starts at a completely different place, with figures of desire, viz. the way names might figure in an open embrace of badnam in the scene of love. It is not only the literary figures of high culture, such as Meera Bai and Majnun, who stake their public reputation by falling in love-madly, insanely, with the wrong kind of person (socially speaking)-yet as they lose their 'name' in the context of the social, they re-emerge with a legendary reputation as lovers in another register of life and literature. Figures in the more raucous public culture of melas (fairs) and folk theatres too celebrate the risky, dangerous terrain of desire. The Bollywood song Bharadwaj cites is 'Munni badnam hui darling tere liye' (Munni became badnam darling, for you), though he does not go to the second line that lustily proclaims, 'Main Jhandu Bam hui darling tere liye' (I became Jhandu Bam [name of a cream to be applied for aches and pains], darling for you), which speaks not to eternal love but to the pleasure of becoming a bazari woman-the common name for a prostitute. ${ }^{17}$ Interestingly, the nautanki song on which the Bollywood song was based was, "launda badnam hua laundi tere liye"18 (the boy became badnam, oh girl, for you). The politics of taking the male common name launda (boy) and replacing it with a female proper name (Munni) in the Bollywood song would take us too far away from the present topic. However, we detect that the love affair of the song casts its shadow on another affair-this time relating to cutting edge stem-cell therapy that the clinical director of a small clinic pursues, but outside global protocols. The badnami, or ignominy, that comes to be attached to her practice raises the question: is the badnami (bad name) borne by her akin to the embrace of badnami by the figures of Meera and Majnu, or is there a taint of commercialism that is hinted at in the Munni song through the features of encryption that Bharadwaj posits as an essential feature of the name? Put more starkly and without the delicacy that Bharadwaj writes with, one might then ask-are those who claim spectacular successes with therapies that are not yet approved pursuing science or sullying it in the bazaar for their own gains? Let us leave Bollywood songs for now and come to the question in a more straightforward way.

The clinical director of the small clinic in Delhi that Bharadwaj documents here and elsewhere, offers embryonic stem cells as therapy for a variety of otherwise incurable conditions, but her therapeutic procedures do not follow international procedures. Although Bharadwaj has followed some patients who were treated in her clinic and who experienced significant improvement in their conditions, one might say, the jury is still out. Meanwhile, the clinic and the claims of the director for the success of stem cell therapy for these conditions has attracted a lot of international and national bad press. She has been accused of being a charlatan who is risking the lives of her patients by giving them untested therapy for her own profit. She claims that conducting double-blind clinical trials, seen as the gold standard for clinical research, would require the setting up of control groups who would receive placebos for comparison with the groups receiving the experimental therapy. However, she does not find it ethical to deny patients therapy when she has evidence she trusts that they can be cured or at least given a new lease of life. In an uncanny way the language she uses contains the very concepts usually promulgated by regulatory regimes (for instance, the ethics of giving placebos when lives are in danger was successfully contested by HIV activists in the eighties; experimental drugs for the terminally ill are made available even before their safety is fully established). Yet mainstream researchers fail to recognise that the concepts the clinical 
director is using in her defence are the same that have been used in exceptional cases when there is a risk of a new epidemic or when patients are terminally ill and may choose to use drugs whose safety and efficacy are not established. Bharadwaj does not offer any judgment on the truth claims of either side. What he does show is that the spectre of badnam falls over this research in part, at least, because it is being done in India. There is a process of contamination in which the name of the clinic comes to be metonymically associated with the name of India, but there is also the opposite move of the restoration of a name. The dynamic of the name he observes is that of a previously good name becoming sullied, even destroyed, and then attempts are made for a new name to be constituted from these debris. Some will reach that point when their reputations will be restored but others, such as Dr Subhas Mukherjee whose claims for having produced the first test-tube baby in India (and the second in the world) were discredited, might be destroyed. Dr Mukherjee took his own life in 1981 and, though he was posthumously honoured for his contributions to reproductive and infertility medicine, he could not survive the dynamic of destruction and reconstruction of names.

It is to the darker potentials contained in the name, that Bharadwaj so nicely sets up, to which we turn in the next and final section. There, we see the intimacy between death and the name in sharper focus.

\section{Death, occult, and the name}

Names make some realities manifest as they also occult other aspects of the real. Bruce's paper on names in Urdu literature allows us to think of the relation between death and names, although it also does many other things. In Urdu poetry, as Bruce points out, it is common to use a pen name, called the takhallus. This is both a practice of self-naming and of self-creating by giving oneself a double. Such doubles were also created in Bollywood films, and Bruce captures nicely the irony with which Manto, the doyen of Urdu literature, reflects on how Muslim names were changed into Hindu names for publicity in order to correct what directors and publicists feared might appear as the disharmony of a Muslim hero portraying, say, a Hindu saint. Manto also produces biting satire on the pretensions of the progressive writers movement, which had castigated and ostracised him for his so-called 'obscenity' in such stories as 'Bu' (smell), through his observations on the literary conventions of takhallus. Bruce cites the following passage:

Qateel Shifai's parents certainly did him wrong when they named him Aurangzeb. Progressive poetry and traditionalist, conservative Aurangzeb!? Who isn't familiar with Miraji's work? He, too, is a poet, and such a progressive poet that most of his work is above and beyond people's understanding. His original name was Sanaullah, the meaning of which is clear [praise of Allah]. If he had remained Sanaullah, he would have been compelled to write poems whose meaning would have been clear, but because this was not Sanaullah's purpose in life, and he wanted to write mysterious kinds of poetry, he had to name himself something of this kind.

Manto is suggesting here the superficial way in which takhallus, the pen name, functions as nothing more than a mask-the real people designated by the conservative names these writers bore as their given names announce themselves not only in their poetry but also in their sensibilities, as displayed in ostracizing Manto even as he was charged under obscenity laws in Pakistan.

Bruce also gives a compelling analysis of the short story, Yazid, on how a man tries to reverse the physiognomy of the hated name Yazid, usually shunned by Muslims for his 
culpability in the death of the Prophet's grandson, Husain. To everyone's surprise, he names his new-born son Yazid and defends his action by saying he hopes for a different kind of Yazid-not a killer but a restorer of life. In the hate-filled post Partition environment of India and Pakistan, this double act of receiving a past differently and changing the way we look at the future as the unfolding of a plot of given enmities is remarkable; and doubly so in that this critique is done through the simple act of naming (see also the discussion by Copeman on aspirations expressed in secular names.) ${ }^{19}$

Bruce opens up a very interesting discussion of what a doubling of a name might mean. His essay takes us to other scenes in Urdu poetry where the name occurs as part of the poem, to elevating or devastating effect. Take Ali Sardar Jafri, an important poet in the progressive writers group, whose writing may not achieve the heights of Manto or Faiz, but who aspires to a death and a rebirth through his poetry. We cite two couplets (our translation).

Phir ik din aisa aayega aankhon ke diye bujh jayenge

Haathon ke kanwal kumhlayenge

Then such a day will come,

the lamps of the eyes will be extinguished

The lotus of the hands will wilt

The thought is carried forward in a deepening imagery of dying and withering to turn at the end toward a scene of regeneration when his spirit will permeate the blue of the rivers and the green of the plants. For our purpose what is most interesting is the use of proper names, his own and that of his wife, toward the end of the poem.

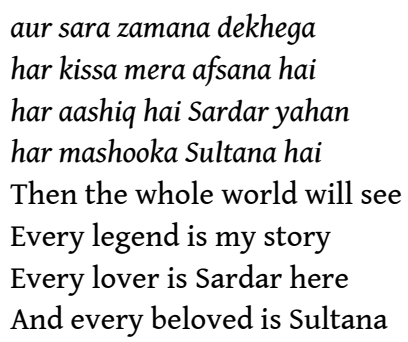

The use by the poet of his own name and the name of his beloved lays claim to the legends of love as telling every ordinary person's story too. Recall here Bharadwaj's discussion of the figures of Meera and Majnun (not to speak of Munni), who embrace the badnami of loving madly. Jafri does a reverse move here-he claims his story to be the story of legends. Sardar and Sultana who love diurnally, it is claimed, are able to suffuse the world with their love as much as those who love eternally. ${ }^{20}$ Names then participate (to use the verb favoured by Mazzarella, rightly we think) in the scene of death but they are also the anchors that help the poet to reach beyond death. ${ }^{21}$

A much darker vision appears in a simple of act of listing names in the Bengali poet Jibanananda Das's poem entitled '1946-1947', perhaps the greatest poem ever written on the violence of the Partition. We give here some fragments in which names appear in the lovely translation by Joe Winter:

They sleep.

If I call then from the wave-roaring river of blood

He will approach and say 'I am Yasin

Hanif Mohammad Maqbool Karim Aziz-

And you? So putting his palm on my chest and raising his eyes

From his dead face he will ask-again the blood-river

Will swell in reply, 'Gagan, Bipin, Shashi of Pathuriaghata, of Maniktala, Shyambbazar, Galif Street, Entally- 
$[\ldots]$

Time speaks; but to whom? Yasin Maqbool, Shashi

Suddenly approach but before they say

It is as if from the deep heart of fragmented eternity

A host of things are said; yet

Eternity is indivisible; and so those dreams

Into undivided eternity have vanished;

No one's there, nothing's there-the sun is extinct.

(Extract from J. Das 2003)

The running sequence of names-immediately recognisable as Muslim on one side and Hindu on the other-condense in themselves everything that was broken and fragmented. Eternity absorbs them, but unlike in the memory of literature, here names are not evoked to make their presence felt but are evoked to say that no traces are left: even the sun is extinct. Hearing lists of names has an uncanny effect. Think of reading the names of Jews who were deported in the small memorials or placards that spring up and confront you in a visit to Berlin-at the Grunwald station, on apartment buildings, on small placards nailed to the street to interrupt your walk (Brandel 2015). Names manifest a ghostly present even as the events are only suggested-not given any detailed description. ${ }^{22}$

The theme that animates Das's paper is that of the unbearable name-both one's own and that of the other. Our names, like our signatures, open the world to us but also open us to the world, and the cases from literature, and from her ethnography that Das directs our eyes toward, are those in which saying or not saying the name is a matter of life and death. Only, the notion of death here is of the harm that human beings do to each other, such that their own or the other's existence itself becomes unbearable to them.

In his remarkable interpretation of the film Now, Voyager, Cavell puts the matter of names as follows:

The story of Now, Voyager can be understood as the retelling of the fantasy of the ugly duckling. It is a recounting for grown-ups of the way a name can make you (count yourself) ugly, that tells how hard it is for a human being to find the way to her or his (legitimate?) name, the name of the kind to which one is kin.' (Cavell 1990: 241)

In the episode from the Ramacharitamans that Das analyses, Bharata (Rama's younger brother) learns the treachery of his mother Kaekeyi in causing Rama to be exiled to the forest so that Bharata could inherit the kingdom. One of the ways Bharata expresses his anguish and shame is to ask if he is worthy of the name he has. To restore one's name to oneself, Das shows, is not simply the work that one does on one's self but also the way in which others can testify to the authenticity of one's name and one's experience to oneself.

The name is also a lethal weapon. In one of the ethnographic vignettes, Das describes the case of a woman who deliberately uses the proper name of her husband precisely in a gesture of breaking the prohibition on wives taking the name of the husband, because it is said that every time a woman pronounces the name of her husband she reduces his life by one day. These are small acts of vengeance the woman performs on her uncaring husband who, as she said, could make her repeatedly pregnant but not care to see that the babies survived. The death of her children encodes for her an uncaring world-and though she might not have the vocabulary to give expression to her rage and despair, the name does it for her. In another case, a woman holds the name of her abuser in her body; tightly enclosing it, for letting it be released in the world would bring absolute chaos. These qualities of the name are addressed in quotidian ways in ritual practices of giving a 
'shield name' (kavach naam) so that sorcerers and demons cannot lay hold of the real one. John Beattie (1957) remarked that personal names among the Banyoro were mostly indicative of the themes of death, sorrow, poverty and neighbourly strife. But if names express the lethal conditions of social life through the singular mechanism of personification, they also provide ways in which we can sense the invisible connections through which we might be connected not only to kin and friends but also to total strangers, as Dowdy shows in describing how he discovered what it is to share a name.

Dowdy's paper concerns the contingent connections that names alert us to and the work that must be done to overcome this contingency. Drawing on long-term fieldwork in Mayong, central Assam, Dowdy points out that personal names unite with the person's body and express his or her destiny, and hence choosing the name of a person is a laborious, high-stakes process. The name is divined via complex ritual procedures involving consumption of and anointment with rice beer, the sacrifice of a red cock, and the divining of auspicious letters from the sacrificed cock's intestines. The name derives from one body, so to speak, before being inserted into another. Despite the care taken and attention to cosmological detail, the name remains a site of acute vulnerability as the potential access point (for a hostile ghost, for instance) to the very life of its bearer. It is therefore perhaps not surprising that the name, in particular situations, becomes a species of tabooed speech ( $c f$. Das this issue). Combining a sophisticated reading of taboo theory with a highly personal account of what it means to utter a name-sharer's name, Dowdy is able to show how two persons having the same name must share some substance and also a common destiny-for the (shared) name has 'a particular fate built into it.' Uttering the name of one's namesake-the taboo in question-activates the latent closeness that the term 'mita' (friend) would euphemise-necessary misrecognition turns into dizzying, dangerous recognition. One's fate is no longer one's own. Maintenance of the taboo does not mean that singularity is maintained, but it does mitigate what might otherwise be a calamitous sense of being overrun by another's lifeworld. More treacherous still, Dowdy's paper carries forth the very transgression it throws light on. 'Of names,' said Hobbes (1651), 'some are 'proper,' and singular to one only thing, as 'Peter,' 'John,' 'this man,' 'this tree'; and some are 'common' to many things, 'man,' 'horse,' 'tree'-every of which, though but one name, is nevertheless the name of divers particular things; in respect of all which together it is called an 'universal,' there being nothing in the world universal but names; for the things named are every one of them individual and singular.' It is not only Dowdy's paper in this volume that complicates such a picture, but it does so in a particularly interesting way. For Hobbes, though one name may indeed be common to many things (name a multiplicity), those things remain in themselves 'individual and singular.' In Mayong, however, the personal name is a kind of substance shared across its bearers and so entwining their fates-and we discussed earlier how sameness of name comes in and out of focus, as of a piece with sameness of substance. While we do not have space to elaborate the particular place of names in conceptions of code-substance, we might conceive of them as a kind of substance open to both monist and dualistic thinking, with the papers in the volume showing tensions between both modes. Where the doubling of the name in takhallus is one of self-naming indistinct from self-creation-compare with Nietzsche's (2004: 52) comments in Ecce Homo on how all prior references to the name of Wagner in his work should be substituted with his own-the doubling of the name in Mayong is one of sheer contingency: the name is doubled on the edge of the abyss. 


\section{BIBLIOGRAPHY}

Appadurai, Arjun (2000) 'Spectral Housing and Urban Cleansing', Public Culture, 12(3), pp. 627-51. Azaryahu, Maoz (2011) 'The Critical Turn and Beyond: The Case of Commemorative Street Naming', ACME: An International E-Journal for Critical Geographies, 10(1), pp. 28-33.

Barrow, Ian J. (2003) 'From Hindustan to India: Naming Change in Changing Names', South Asia: Journal of South Asian Studies, 26(1), pp. 37-49.

Beattie, John (1957) ‘Nyoro Personal Names’, Uganda Journal XXI(1), pp. 99-106.

Benoist, Jocelyn (2008) ‘Le “dernier pas” du structuralisme : Lévi-Strauss et le dépassement du modèle linguiste', Philosophie, 98, pp. 54-70.

Brandel, Andrew (2015) ‘Walking the City: A Flâneur in Berlin', unpublished manuscript.

Broom, Leonard; Beem, Helen P.; Harris, Virginia (1955) 'Characteristics of 1,107 Petitioners for Change of Name', American Sociological Review, 20(1), pp. 33-39.

Cavell, Stanley (1981) Pursuits of Happiness: The Hollywood Comedy of Remarriage, Cambridge: Harvard University Press.

Cavell, Stanley (1990) ‘Ugly Duckling, Funny Butterfly: Bette Davis and “Now, Voyager”', Critical Inquiry, 16(2), pp. 213-47.

Chatterji, Roma (2012) Speaking with Pictures: Folk Art and the Narrative Tradition in India, New Delhi: Routledge.

Cohen, Lawrence (2010) 'Ethical Publicity: On Transplant Victims, Wounded Communities, and the Moral Demands of Dreaming', in Anand Pandian \& Daud Ali (eds.), Ethical Life in South Asia, Bloomington (Indiana): Indiana University Press, pp. 253-274.

Cohen, Lawrence (2012) '1', presented at the Annual Conference on South Asia, Madison (Wisconsin), online at http://followuidai.wordpress.com

Connerton, Paul (2008) ‘Seven Types of Forgetting’, Memory Studies, 1(1), pp. 59-71.

Cooper, Michael J.; Gulen, Huseyin; Rau, P. Raghavendra (2005) 'Changing Names With Style: Mutual Fund Name Changes and Their Effects on Fund Flows', The Journal of Finance, 60(6), pp. 2825-58.

Copeman, Jacob (2012) 'The Mimetic Guru: Tracing the Real in Sikh-Dera Sacha Sauda Relations', in Jacob Copeman \& Aya Ikegame (eds.), The Guru in South Asia: New Interdisciplinary Perspectives, London: Routledge, pp. 156-80.

Das, Jibanananda (2003) Jibanananda Das: Naked Lonely Hand-Selected Poems, Joe Winter (trans.), London: Anvil Press Poetry Ltd.

Das, Veena (1976) Structure and Cognition: Aspects of Hindu Caste and Ritual, Delhi: Oxford University Press.

Das, Veena (1983) 'Language of Sacrifice', Man, 18(3), pp. 445-62.

Das, Veena (2009) 'If This Be Magic... Excursions into Contemporary Hindu Lives', in Hent de Vries (ed.), Religion Beyond a Concept, New York: Fordham University Press. 
Das, Veena; Jackson, Michael D.; Kleinman, Arthur; Singh, Bhrigupati (2014) 'Introduction; Experiments between Anthropology and Philosophy: Affinities and Antagonism', in Veena Das, Michael D. Jackson, Arthur Kleinman \& Bhrigupati Singh (eds.), The Ground Between: Anthropologists Engage Philosophy, Durham: Duke University Press, pp. 1-26.

Das, Veena (2015) 'What Does Ordinary Ethics Look Like?', in Michael Lambek, Veena Das, Didier Fassin \& Webb Keane, Four Lectures on Ethics, Chicago: The University of Chicago Press.

Derrida, Jacques (1995) On the Name, Stanford: Stanford University Press.

Deseriis, Marco (2015) Improper Names: Collective Pseudonyms from the Luddites to Anonymous, Minneapolis: University of Minnesota Press.

Erdem, Tülin; Swait, Joffre (1998) ‘Brand Equity as a Signaling Phenomenon', Journal of Consumer Psychology, 7(2), pp. 131-57.

Frege, Gottlob (1993) 'On Sense and Reference', in Alan W. Moore (ed.), Meaning and Reference, Oxford: Oxford University Press.

Ghosh, Amitav (2008) Sea of Poppies, London: John Murray.

Guha, Ranajit (2001) History at the Limits of World History, New York: Columbia University Press.

Hansen, Thomas (2001) Wages of Violence: Naming and Identity in Postcolonial Bombay, Princeton: Princeton University Press.

Henn, Alexander (2014) Hindu-Catholic Encounters in Goa: Religion, Colonialism, and Modernity, Bloomington: Indiana University Press.

Hobbes, Thomas (1651) Leviathan, London: Andrew Crooke.

Husserl, E. (1960 [1931]) Cartesian Meditations. D. Cairns (trans.), Dordrecht: Kluwer.

Inden, Ronald (1976) Marriage and Rank in Bengali Culture: A History of Caste and Clan in Middle-period Bengal, Berkeley: University of California Press.

Jayswal, Smita Tewari (2001) 'Caste and the Colonial State: Mallahs in the Census', Contributions to Indian Sociology, 35(3), pp. 319-54.

Kapila, Kriti (forthcoming) 'Unpopular Justice: Law and the Inexpediency of Culture in North India', Comparative Studies in Society and History.

Kellenberger, J. (1979) 'The Ineffabilities of Mysticism', American Philosophical Quarterly, 16(4), pp. 307-15.

Khosravi, Shahram (2012) 'White Masks/Muslim Names: Immigrants and Name-Changing in Sweden', Race \& Class, 53(3), pp. 65-80.

Kripke, Saul (1980) Naming and Necessity, Oxford: Blackwell.

Lambek, Michael (2009) 'Provincializing God? Provocations from an Anthropology of Religion', in Hent de Vries (ed.), Religion Beyond a Concept, New York: Fordham University Press, pp. 120-38.

Lévi-Strauss, Claude (1966) The Savage Mind, Oxford: Oxford University Press.

Lévy-Bruhl, Lucien (1985 [1926]) How Natives Think, Lilian A. Clare (trans.), London: George Allen \& Unwin.

Malamoud, Charles (1998) 'Rite, simulacre, théâtre : Observations sur les éléments dramatiques dans le culte solennel védique', Purusārtha, 20, pp. 25-43. 
Mehta, Deepak (2015) 'The Ayodhya Dispute: Law's Imagination and the Function of the Status Quo', in Roma Chatterji (ed.), Wording the World: Veena Das and Scenes of Inheritance, New York: Fordham University Press, pp. 173-287.

Menon, Nivedita (2012) Seeing Like A Feminist, Delhi: Penguin.

Naipual, V.S. (2002 [1963]) 'Jamshed into Jimmy', in The Writer and the World, London: Picador.

Nandy, Ashis (1995) ‘History’s Forgotten Doubles', History and Theory, 34(2), pp. 44-66.

Nesfield, John Collinson (1885) Brief View of the Caste System of the North-Western Provinces and Oudh: Together with an Examination of the Names and Figures Shown in the Census Report, 1882; Being an Attempt to Classify on a Functional Basis All the Main Castes of the United Provinces, and to Explain Their Gradations of Rank and the Process of Their Formation, North-Western Provinces \& Oudh Government Press.

Nietzsche, Friedrich (2004) Ecce Homo, New York: Algora Publishing.

Peirce, Charles S. (1903) Speculative Grammar: Collected Papers, Cambridge: Harvard University Press.

Peirce, Charles S. (1931-1958) Collected Papers of Charles Sanders Peirce, 8 vols., vols. 1-6 Charles Hartshorne \& Paul Weiss (eds.), vols. 7-8 Arthur W. Burks (ed.), Cambridge: Harvard University Press.

Pietarinen, Ahti-Veikko (2010) 'Peirce's Pragmatic Theory of Proper Names', Transactions of the Charles S. Peirce Society: A Quarterly Journal in American Philosophy, 46(3), pp. 341-63.

Pinney, Christopher (1997) Camera Indica: The Social Life of Indian Photographs, London: Reaktion books.

Rao, Velcheru Narayana; Shulman, David; Subrahmanyam, Sanjay (2001) Textures of Time: Writing History in South India 1600-1800, Delhi: Permanent Black.

Recanati, Francois (1997) Direct Reference: From Language to Thought, Oxford: Blackwell.

Rege, Sharmila (2006) Writing Caste, Writing Gender: Reading Dalit Women's Testimonies, Delhi: Zubaan.

Robinson, Rowena (2000) ‘Taboo or Veiled Consent? Goan Inquisitorial Edict of 1736', Economic and Political Weekly, pp. 2423-31.

Russell, Bertrand (1911) 'Knowledge by Acquaintance and by Description', Proceedings of the Aristotelian Society, XI, pp. 108-28

Schutz, Alfred; Luckmann, Thomas (1989) Structures of the Life-World, vol. 2, Evanston (Illinois): Northwestern University Press.

Scott, James C. (1998) Seeing Like A State: How Certain Schemes to Improve the Human Condition Have Failed, New Haven: Yale University Press.

Scott, James C.; Tehranian, John; Mathias, Jeremy (2002) 'The Production of Legal Identities Proper to States: The Case of the Permanent Family Surname', Comparative Studies in Society and History, 44(1), pp. 4-44.

Searle, John R. (1958) ‘Proper Names’, Mind, 67(266), pp. 166-73.

Sharma, D. D. (2005) Panorama of Indian Anthroponomy: An Historical, Socio-cultural and Linguistic Analysis of Indian Personal Names, Delhi: Mittal Publications. 
Sikand, Yoginder; Katju, Manjari (1994) 'Mass Conversions to Hinduism among Indian Muslims', Economic and Political Weekly, 2214-19.

Singha, Radhika (1998) A Despotism of Law: Crime and Criminal Justice in Colonial India, Oxford University Press: Delhi.

Singha, Radhika (2000) 'Settle, Mobilize, Verify: Identification Practices in Colonial India', Studies in History, 16(2), pp. 151-98 [version consulted: http://www.oslo2000.uio.no/program/papers/s4/ s4-singha.pdf]

Srinivas, Mysore Narasimhachar (1957) 'Caste in Modern India', The Journal of Asian Studies, pp. 529-48.

Teisl, Mario F.; Roe, Brian (1998) 'The Economics of Labelling: An Overview of Issues for Health and Environmental Disclosure', Agricultural and Resource Economics Review, 27, pp. 140-50.

Virani, Shafique N. (2011) 'Taqiyya and Identity in a South Asian Community', Journal of Asian Studies 70(1), pp. 99-139.

Viswanath, Rupa (2013) 'The Emergence of Authenticity Talk and the Giving of Accounts: Conversion as Movement of the Soul in South India, ca. 1900', Comparative Studies in Society and History, 55(1), pp. 120-141.

Weber, Eric Thomas (2008) 'Proper Names and Persons: Peirce's Semiotic Consideration of Proper Names', Transactions of the Charles S. Peirce Society, 44(2), pp. 346-62.

\section{NOTES}

1. For further elaboration on concepts such as life and having a life, see Das (2015).

2. The colonial adoption of early biometric forms such as fingerprinting (Singha 2000) and photography (Pinney 1997) was in part designed to mitigate the recurrence and changeability of personal names. But onomastic recurrence was and is still foregrounded as a problem, from confusion at the Kumbh Mela when public announcements of the names of one or two lost children are responded to by thousands of pilgrims (Sharma 2005: 127), to complaints about the weak referentiality of Sikh surnames Singh and Kaur (see below), to the ghostly duplication of names (without bodies) that the present-day Aadhaar biometric scheme seeks to 'correct' but frequently ends up reproducing (Cohen 2012).

3. The focus of his Deseriis's work is on collective pseudonyms as multiple-use aliases employed by activists at times of political crisis when extant modes of address and reference fall short. His case studies extend from Ned Ludd through to the Internet collective Anonymous. See below on another kind of shield name.

4. http://ww2.kqed.org/news/09/16/FacebookDragQueens

5. The weak referentiality of Singh and Kaur can provide travel and immigration problems for Sikhs. The Canadian government, for instance, had a longstanding policy of rejecting applications offering such names as surnames, forcing applicants to legally change/add to their names. Often, the additional name would be a caste name. With more than an echo of the nominative politics of the colonial census, caste titles are thus instituted due less to resurgence of a 'caste mentality' than a bureaucratic demand to fix the reference. South Indian naming conventions also frequently present a problem of legibility for western visa and immigration authorities: length of name, absence of surname, and use of initials are all cited as reasons for this. But use of initials had other, altogether more constructive effects: 'There was an interesting way in which the English language became handy for the [low-caste] community. Several people of Urmilatai's [Pawar] generation and even some older ones changed their derogatory or godly 
first names by adopting English initials-like L.R. Tambe or K.D. Kadam for instance' (Rege 2006: 289). See also Bruce's paper in this volume on Urdu writers' use of initials.

6. The sovereign gifts of censorship and of the name converge completely in the Censor Board's inclusion of Bombay on a list of proscribed words. Thanks to Edward Anderson for alerting us to this.

7. Times of India, 22 Nov. 2014.

8. On the origins of the importance of the name of Rama in bhakti worship see Doniger (2009: 247-48).

9. Puranas are a genre of sacred text through which the history of a kingdom, a community, or a place is recorded. Although there is an interesting debate in India about the specific texture of texts that stylistically code historical consciousness versus the claim that the very notion of history is at stake, we take the Puranas and mahātmyas on their own terms as far as the arguments on names are concerned (see Das 1976, Guha 2001, Nandy 1995, Rao et al. 2001).

10. See discussion in Menon (2012) on the politics of maiden names, and the work of Dr Sudha Kankaria's Beti Bachav (Save Girl Child) NGO which, amongst other gender equality programmes, has conducted mass renaming ceremonies for girls (usually the third or fourth born) with the name Nakusa or Nakoshi (Unwanted) in Satara Dist., Maharashtra.

11. http://www.ndtv.com/india-news/read-shah-rukh-khans-article-which-appeared-inoutlook-turning-points-2013-511771. See Copeman's paper in this issue on the name of Shahrukh and Gauri Khan's third child, AbRam.

12. A radically monotheistic socio-religious organisation, the Arya Samaj has engaged in Hindu reformist activity since its inception in 1875 by Swami Dayananda Saraswati, pursuing campaigns against idolatry and caste.

13. See Virani (2011) for a related discussion of Ismaeli Guptis of Bhavnagar, whose 'precautionary dissimulation' takes the form not of Sunni imitation (as is more common among Ismaelis in other places), but of passing as Hindus, for instance, through the use of identifiably Hindu names.

14. Compare with the medieval Hindu-Sanskritic glosses for words and names introduced to the region by the Turks, where "the Ghorids became the Gauri-kula ("family of fair people" or "family of the golden goddess [Parvati]"), sultans became Sura-tranas ("protectors of the gods"), and Mohammad (or Mahmud) became Maha-muda ("great joy")' (Doniger 2009: 447). See also Barrow (2003) for the name of the country as Hindustan.

15. As Husserl (1960: 109) put it, 'the strictly seen front of a physical thing always and necessarily appresents a rear aspect and prescribes for it a more or less determinate content' (Husserl 1960: 109). But if the accent in brand names is on quality, with gods it is qualities. A corollary to the Godhead or Brahman being free of, or beyond, all names (Kellenberger 1979) can be their having very many of them. 'The Vishnu Sahasranama enumerates the god's 1,000 names. The name he is known by is 'according to the aspect [of his divinity] envisaged' (Daniélo 1991: 151). The relation between namelessness and having many names is also explored in Steinberg's paper in this volume.

16. See also Das (2015) for a related discussion on how the movement between the first, second, and third person was central to the theories of the grammatical person of the Kashmiri philosopher Abhinavgupta (late $10^{\text {th }}$, early $11^{\text {th }}$ century) and the understanding of what it is to become a sentient being through being addressed.

17. Notice the movement from the third person in the first line (Munni) and the first person in the second line (main).

18. Nautanki refers to a genre of popular theatre performed in fairs and festivals in different parts of north India. I (Veena) recalled this song from one such nautanki fair held in Meerut in 1952, which I attended as a small child tagging along with other adults from a nearby village in which I lived for a short period. In much of popular media now, this song is referred to as a 
Bhojpuri song. Neither of the two editors have the expertise to determine the correct origin of the song.

19. See also Copeman (2012) for a related discussion on how (re)naming is central to a critique of Sikh orthodoxy enacted by the devotional movement the Dera Sacha Sauda. Sovereign acts of (re)naming may authorise particular criticisms and sentiments as legitimate-as in removing the entitlement of using the prefix 'sir' from disgraced UK public figures.

20. It is always easier to love eternally than to love diurnally, as the philosopher Stanley Cavell (1981) once remarked.

21. Though this might take us a little away from the discussion at hand, we cannot help citing the couplets from a poem by Faiz Ahmed Faiz: 'maidan-e-wafa darbar nahin, yahan namo-nasal ki pooch kahan, kuch ishq kisi ki zaat nahin, aashiq to kisi ka naam nahin' (the field of love is not a royal court, no one asks for name or title here; love is not the name of anyone's caste, nor is lover the name of a person).

22. Further uneasiness arises from the role of name lists as accessories to the events they are also used to remember. Writing of the riots in Mumbai after the demolition of the Babri Masjid mosque in Ayodhya on December 6 1992, Appadurai (2000: 648) notes how 'Muslims were cornered in slums and middle-class areas, in their own crowded spaces, hunted down with lists of names in the hands of organised mobs.'

INDEX

Keywords: names, naming, brand names, vulnerability, deities, translation, place names, description, singularity, dissimulation, name change, death, occult, publicity, reference, state

\section{AUTHORS}

\section{VEENA DAS}

Department of Anthropology, John Hopkins University, Baltimore

\section{JACOB COPEMAN}

School of Social and Political Science, University of Edinburgh 